Volume 8

Number 2 Student Articles Edition

Article 3

2-16-2022

\title{
VARA Turns Thirty-One: How Amending the Visual Artists Rights Act of 1990 to Add Guiding Language Can Further Advance the Act's Purpose
}

Ana-Victoria Moreno

Texas A\&M University School of Law (Student), amorenosch@tamu.edu

Follow this and additional works at: https://scholarship.law.tamu.edu/journal-of-property-law

Part of the Entertainment, Arts, and Sports Law Commons, Intellectual Property Law Commons, and the Property Law and Real Estate Commons

\section{Recommended Citation}

Ana-Victoria Moreno, VARA Turns Thirty-One: How Amending the Visual Artists Rights Act of 1990 to Add Guiding Language Can Further Advance the Act's Purpose, 8 Tex. A\&M J. Prop. L. 103 (2022).

Available at: https://doi.org/10.37419/JPL.V8.12.3

This Notes \& Comments is brought to you for free and open access by Texas A\&M Law Scholarship. It has been accepted for inclusion in Texas A\&M Journal of Property Law by an authorized editor of Texas A\&M Law Scholarship. For more information, please contact aretteen@law.tamu.edu. 


\title{
VARA TURNS THIRTY-ONE: HOW AMENDING THE VISUAL ARTists Rights ACT OF 1990 TO AdD GUIDING LANGUAGE CAN FurThER ADVANCE THE ACT's PURPOSE
}

\author{
Ana-Victoria Moreno ${ }^{\dagger}$
}

\begin{abstract}
Congress passed the Visual Artists Rights Act ("VARA") in 1990, introducing the doctrine of moral rights into United States law. ${ }^{1}$ Moral rights consist of four rights: attribution, disclosure, withdrawal, and integrity. ${ }^{2}$ VARA recognizes the rights of attribution and integrity to preserve the integrity of artworks and of the country's cultural heritage by encouraging artists to create. ${ }^{3}$ The passing of VARA has been met with criticism ${ }^{4}$ but also with excitement that Congress recognized the importance of artists' non-economic rights. ${ }^{5}$ In the thirty-one years since the enactment of VARA, caselaw has developed that shows how courts and parties are interpreting its language. ${ }^{6}$ One main issue with
\end{abstract}

DOI: https://doi.org/10.37419/JPL.V8.I2.3

$\dagger J . D$. Candidate, Texas A\&M University School of Law, Spring 2022. I would like to thank my parents for their unwavering support, Chase Archer for tackling law school with me, and my partner in everything, Erik Carvajal, for always believing in me. I am also grateful for the Texas A\&M Law School community-notably Professor Jeff Slattery for serving as my faculty advisor and offering his indispensable advice and guidance throughout this entire process, my Note and Comment Editor Ryan Cairns, and my Executive Editor MacKenzie Dunnehoo for their encouragement and feedback, and all of the Journal of Property Law staffers who edited this Comment.

1. Jane C. Ginsburg, Copyright in the 101st Congress: Commentary on the Visual Artists Rights Act and the Architectural Works Copyright Protection Act of 1990, 14 COLUM.-VLA J.L. \& ARTS 477, 478 (1990).

2. Michael Rushton, The Moral Rights of Artists: Droit Moral ou Droit Pécuniaire?, 22 J. CULTURAL ECON. 15, 15 (1998).

3. H.R. REP. NO. 101-514, at 14 (1990), as reprinted in 1990 U.S.C.C.A.N. $6915,6924$.

4. See Ilhyung Lee, Toward an American Moral Rights in Copyright, 58 WASH. \& LEE L. REV. 795, 811 (2001).

5. See H.R. Rep. No. 101-514, at 16 (1990), as reprinted in 1990 U.S.C.C.A.N. 6915,6926 (noting that artists' rights are separate from economic rights).

6. See U.S. Copyright OFF., Authors, Attribution, AND InTEgrity: EXAmining Moral Rights IN THE United States 7, 61 (2019), https://www.copyright.gov/policy/moralrights/full-report.pdf [https://perma.cc/5HE5-VPAG]. 
VARA as written is that there is a lack of guidance in interpreting the standards, which has created some judicial confusion. ${ }^{7}$ If Congress were to amend VARA to provide more guiding language, it would give courts a clear and detailed framework when interpreting it. While some degree offlexibility must be maintained, additional guiding language would further promote VARA's purpose and ensures fairness.

I. INTRODUCTION. 104

II. HISTORY LEADING TO THE UNITED STATES' ENACTMENT OF THE VISUAL ARTISTS RIGHTS ACT OF 1990.

A. Origins of the "Droit Morale" or Moral Rights ............ 107

$B$. The Creation and Accomplishments of the Berne Convention.

C. Introduction of Moral Rights into the United States

1. Why the United States did not initially participate in the Berne Convention 112

2. How Moral Rights Differ from Traditional U.S.

Copyright Law.

3. Factors that Led the United States to Adopt Moral

Rights.

III. CURRENT ISSUES WITH VARA …................................................ 119

A. First Amendment Constitutional Issues......................... 119

B. Interpretation Issues .................................................. 121

1. Recognized Stature \& Honor or Reputation: Different or Interrelated Concepts?.... 121

2. Recognized Stature \& Community .......................... 123

3. Aesthetic Interpretation ........................................ 126

IV. ANALYSIS

A. The U.S. Copyright Office conducted a survey and created

a report in 2019 analyzing moral rights..................... 128

B. VARA at Work: The 5Pointz Litigation .......................... 133

V. CONCLUSION 138

\section{INTRODUCTION}

“An artist's professional and personal identity is embodied in each work created by that artist . . . . It is a rebuke to the dignity of the visual artist that our copyright law allows distortion, modification, and even outright permanent destruction of such efforts."

7. See id. at 77.

8. H.R. Rep. No. 101-514, at 15 (1990), as reprinted in 1990 U.S.C.C.A.N. 6915,6925 . 
who represented various artistic interests and testified before Congress during the creation of the Visual Artists Rights Act ("VARA"), illustrates in this statement how failure to recognize the non-economic interests of an artist strips artists of their dignity. Immanuel Kant, whose ideologies helped shape French law, defended copyright based on the importance of recognizing that a creation was essentially an extension of the artist and required protections that went beyond a compensatory basis. ${ }^{9}$ This ideology gave rise to the moral rights doctrine, which essentially gives artists non-economic rights to protect their works from destruction. ${ }^{10}$

The Berne Convention, signed in 1886 by an organization of countries seeking international copyright protection, adopted four previously recognized moral rights in $1928 .{ }^{11}$ The United States joined the Berne Convention in 1989 after thorough consideration of whether joining the Convention would require the United States to pass new laws to protect moral rights. ${ }^{12}$ Because moral rights are inherently at odds with the economic foundation of U.S. copyright law, ${ }^{13}$ the country approached adherence to the Berne Convention with a minimalist approach, only making minimal changes to existing U.S. law to achieve a basic level of Berne compatibility. ${ }^{14}$ VARA, the first introduction of moral rights into U.S. law, brings the U.S. into greater harmony with the Berne Convention's recognition of moral rights ${ }^{15}$ by recognizing two out of the four moral rights. ${ }^{16}$ As thirty-one years have passed since enactment, a review and analysis are due to see whether VARA is furthering its legislative purpose.

9. Rushton, supra note 2, at 17.

10. Id.

11. Id. at 16 .

12. H.R. Rep. No. 101-514, at 7 (1990), as reprinted in 1990 U.S.C.C.A.N. 6915, 6917.

13. See generally Jane C. Ginsburg, A Tale of Two Copyrights: Literary Property in Revolutionary France and America, 64 TUL. L. REV. 991,992 (1990) (stating that the U.S. Constitution's copyright clause makes the public's interest at least equal, if not superior, to the author's interest and encourages the maximization of "production of and access to intellectual creations.").

14. Jane C. Ginsburg \& John M. Kernochan, One Hundred and Two Years Later: The U.S. Joins the Berne Convention, 13 ColuM.-VLA J.L. \& ARTS 1, 6 (1989).

15. H.R. Rep. No. 101-514, at 10 (1990), as reprinted in 1990 U.S.C.C.A.N. 6915,6920 .

16. Ginsburg \& Kernochan, supra note 14, at 27. 
The introduction of VARA in 1990 showed the United States' commitment to recognizing moral rights ${ }^{17}$ - to some extent. It is an exciting possibility to see how Congress and courts will continue to shape the moral rights framework to fit within fundamental U.S. legal principles. This Comment suggests that Congress should amend VARA to include certain language recommended by the U.S. Copyright Office. This language is based on the California Art Preservation Act and provides guidance to courts in making a "recognized stature" determination, which VARA requires for certain types of harm to be actionable. ${ }^{18}$ If the California Art Preservation Act language is federalized, Congress should further define the meaning of "relevant community." These amendments would bolster VARA's effectiveness by resolving some tension in the courts and providing artists basic fairness. A discussion promoting VARA would be incomplete without addressing some criticisms of it. Thus, this Comment covers three prominent critiques of VARA: the tension with the First Amendment, the encouragement that courts undertake aesthetic interpretation when analyzing the recognized stature standard, and the tension with property rights. ${ }^{19}$ While these critiques are important to consider, they should not be used as a basis for completely discounting moral rights. Additionally, this Comment explores the most recent and prevalent VARA litigation, Castillo et al. v. G\&M Realty, L.P., (commonly known as "5Pointz"), to illustrate how VARA can protect artists. ${ }^{20}$ As this Comment will show, the suggested approach of adding clarifying language to recognized stature and "relevant community" would further ensure fair and accurate protection of artists' moral rights.

Section II provides chronological historical background to VARA by tracing the origins of moral rights in France and Germany.

17. See H.R. ReP. No. 101-514, at 10 (1990), as reprinted in 1990 U.S.C.C.A.N. $6915,6920$.

18. U.S. COPYRIGHT OFF., supra note 6, at 5,68.

19. See infra Section III. See generally Dana L. Burton, Artists' Moral Rights: Controversy and the Visual Artists Rights Act, 48 SMU L. REv. 639 (1995); Matt Williams, Balancing Free Speech Interests: The Traditional Contours of Copyright Protection and the Visual Artists' Rights Act, 13 UCLA ENT. L. REV. 105 (2005); Claire Leonard, Copyright, Moral Rights and the First Amendment: The Problems of Integrity and Compulsory Speech, 35 COLUM. J.L. \& ARTS 293 (2012); Amy M. Adler, Against Moral Rights, 97 CAL. L. Rev. 263 (2009).

20. 950 F.3d 155 (2d Cir. 2020); Louise Carron, Case Review of the 5Pointz Appeal, CTR. FOR ART L. (Mar. 2, 2020), https://itsartlaw.org/2020/03/02/case-review-castillo-et-al-v-gm-realty-1-p/ [https://perma.cc/ST2M-BDCL]. 
It then covers the creation of the Berne Convention and the developments it achieved through the twentieth century. This section explains the introduction of moral rights to United States' copyright law. First, it analyzes why the United States was not originally in the Berne Convention. Then, it covers how moral rights differ significantly from United States copyright law and what factors led the United States to eventually adopt moral rights by passing VARA.

Section III highlights First Amendment constitutional issues and interpretation issues that have come up since VARA was enacted. The section covers three particular interpretation issues: two dealing with the interpretation of the recognized stature standard and one dealing with aesthetic interpretation. Section IV argues Congress should amend VARA to include clarifying language for the recognized stature standard as recommended by the U.S. Copyright Office and should further clarify the term "relevant community." It starts by elaborating on the U.S. Copyright Office's report on VARA from 2019. It then covers the 5Pointz litigation as an example of VARA serving an important public interest and addresses the tension between VARA and property rights. Lastly, this section concludes that amending the language as suggested would further Congress' goals and briefly covers the implication of the Supreme Court's denial of the 5Pointz defendant's petition.

\section{HISTORY LEADING TO THE UNITED STATES' ENACTMENT OF THE VISUAL ARTISTS RIGHTS ACT OF 1990}

\section{A. Origins of the "Droit Morale" or Moral Rights}

The invention of the printing press gave booksellers the ability to quickly duplicate authors' manuscripts, which up until that time took far longer. ${ }^{21}$ Unfortunately, this invention gave rise to pirate booksellers who could simply copy manuscripts already published by the legitimate booksellers and sell them for much lower prices. ${ }^{22}$ It became clear that legal protection was necessary because authors and legitimate booksellers were left with no legal recourse against the pirate booksellers exploiting their work. ${ }^{23}$ Originally, the legitimate

21. Peter Burger, The Berne Convention: Its History and Its Key Role in the Future, 3 J.L. \& TECH. 1, 3 (1988).

22. $I d$.

23. $I d$. 
booksellers took the lead by securing protection in the form of a "privilege." 24 This privilege gave booksellers the exclusive right to print and sell a specific author's manuscripts for a limited time. ${ }^{25}$ This privilege system lasted for two hundred years but eventually dissipated because booksellers were taking advantage of their power, governments matured so there was less need for censorship, and authors became more active in lobbying for their own protection. ${ }^{26}$ A statutory form of protection replaced the privilege system. ${ }^{27}$

The statutory protection was the first instance where protection for creative works was based on the rights of authors; this began the philosophical debate of economic interests versus natural rights. ${ }^{28} \mathrm{Be}-$ cause the booksellers were not the creators of the work, they had a purely economic interest. On the other hand, the ideas behind the works belonged to the authors who created those works. Philosophers used natural law as the basis for arguing that an author's economic and personal interests should both be protected..$^{29}$ Great Britain and the United States partially rejected this natural rights approach. ${ }^{30}$ Statutes developed in both countries that gave authors an exclusive, but timelimited, right to prevent others from copying their work without their authorization to protect the economic rights of authors and publishers. ${ }^{31}$ In contrast, the natural rights approach was adopted by continental Europe, which allowed authors to retain rights even if they alienated their economic rights by selling the rights to a publisher. ${ }^{32}$ These became known as "moral rights."

Continental European copyright theory recognizes droit d'auteur - the right of the author to have moral and economic rights in their works. ${ }^{33}$ In a landmark French case, the sculptor, Clesinger, brought an action against transferees of a statue he had created that the transferees mutilated. ${ }^{34}$ The court stated that independent of any economic

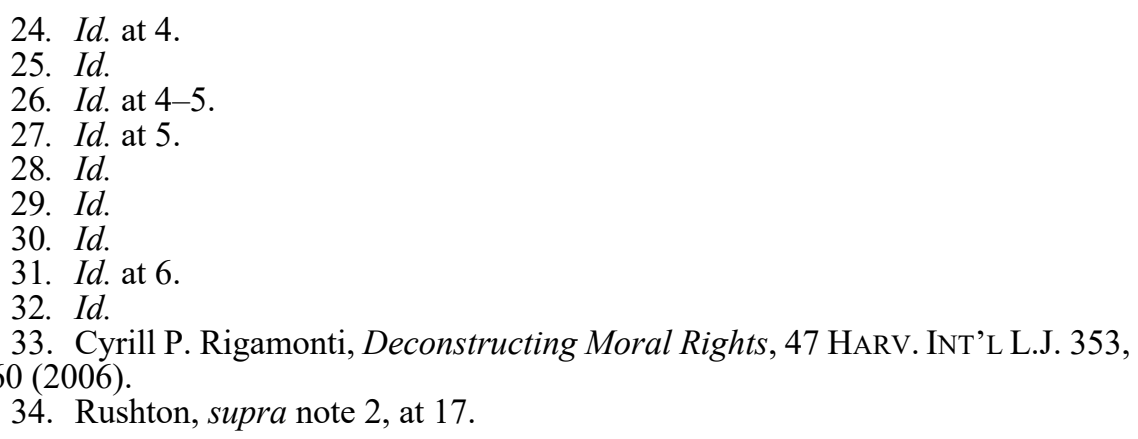


interest in a work, an artist held a more precious interest - that of his reputation. ${ }^{35}$ This case, as well as the ideologies underpinning droit d'auteur, show the concerns of ethics and justice in going beyond the mere economic interest of an author. ${ }^{36}$

The ideology of moral rights developed in France and Germany in the 19th century. ${ }^{37}$ The moral rights doctrine encompasses four separate rights. ${ }^{38}$ These four separate rights are as follows:

(1) attribution or paternity - the right to be identified as the creator of a work, to use a pseudonym, or to remain anonymous; (2) integrity - the right to protect against alteration or mutilation of a work; (3) disclosure - the right to publish or not to publish a work; and (4) withdrawal - the right to remove a work from circulation. ${ }^{39}$

Through the latter part of the 19th century, the French civil courts recognized each of these rights. ${ }^{40}$ In 1901, France's highest court recognized those rights as well. ${ }^{41}$ Fast-forward to modern times and moral rights are now embedded in French and German copyright statutes. ${ }^{42}$ The decision to include moral rights within copyright statutes was not arbitrary. ${ }^{43}$ Moral rights, similar to economic rights, are rights in copyrightable works. ${ }^{44}$ Thus, the copyright statutes in both France and Germany recognize "two attributes and objectives of copyright protection: one moral and the other economic." 45 Two of the rights that make up the larger doctrine of moral rights recognized in France and Germany would eventually be recognized in the Berne Convention of $1928 .{ }^{46}$

35. $I d$.

36. Calvin D. Peeler, From the Providence of Kings to Copyrighted Things (and French Moral Rights), 9 IND. INT'L \& COMP. L. REV. 423, 432 (1999).

37. Rushton, supra note 2, at 16.

38. Peeler, supra note 36, at 426.

39. Rushton, supra note 2, at 16.

40. Id. at 17 .

41. Id.

42. Rigamonti, supra note 33 , at 360 .

43. $I d$.

44. $I d$.

45. Id.

46. Rushton, supra note 2, at 17. 


\section{B. The Creation and Accomplishments of the Berne Convention}

In the late 19th century, the idea of international protection for the rights of authors gained momentum in Europe. ${ }^{47}$ The development of copyright and the focus on authors' rights made authors an influential-political group. ${ }^{48}$ In 1858, the first international Congress of Authors and Artists met in Brussels. ${ }^{49}$ The group served as the foundation for the drafting and signing of the Berne Convention. ${ }^{50}$ Following a few meetings of the Congress, a new International Association, initially comprised only of authors, called a meeting in 1883 to create a union for the protection of literary property. ${ }^{51}$ Subsequent meetings were held in 1884,1885 , and $1886 .{ }^{52}$ In 1886 , ten countries singed the Berne Convention drafted in 1885, which was then ratified in $1887 .{ }^{53}$ The ratification of the Berne Convention was a significant step toward international copyright protection for authors and artists. ${ }^{54}$ It also provided a middle ground for countries that preferred common law legislation by including provisions preserving the application of national law. ${ }^{55}$ National treatment continues to be a guiding principle of the Berne Convention. ${ }^{56}$ This principle calls for reciprocal treatment by requiring that Berne signatories give authors and artists who are nationals of other Berne countries the same protection they give to their own nationals. ${ }^{57}$

A statement of moral rights came into the Berne Convention in $1928,{ }^{58}$ when 36 country members met in Rome. ${ }^{59}$ While a growing membership was positive, it also made unanimous decisions much more difficult to reach. ${ }^{60}$ The 1928 revisions increased the number of works protected, added to the number of exclusive rights, and limited

47. Burger, supra note 21, at 11.

48. Id.

49. Id.

50. $I d$.

51. Id. at $11-12$.

52. $I d$. at 12 .

53. $I d$. at 15 .

54. $I d$.

55. $I d$.

56. $I d$. at 16 .

57. Id. at $16-17$.

58. Rushton, supra note 2, at 16.

59. Burger, supra note 21, at 27.

60. Id. 
the use of reservations. ${ }^{61}$ Moral rights were one of the two new exclusive rights added at this Convention. ${ }^{62}$ Article $6^{\text {bis }}$ of the Berne Convention recognized the author had "the right to claim authorship of the work and to object to any distortion, mutilation, or other modification of, or other derogatory action in relation to, the said work, which would be prejudicial to his honor or reputation." ${ }^{63}$ In line with the doctrine of moral rights more broadly, the Article recognized that these rights were inalienable and independent from the author's economic rights. ${ }^{64}$ While the Berne Convention also included the rights of paternity and integrity, the rights of disclosure or withdrawal were not included. ${ }^{65}$ As part of the introduction of moral rights into the Berne Convention, each contracting state could decide how exactly the required moral rights would fit within each state's domestic legislative framework. ${ }^{66}$ Specifically, Article $6^{\text {bis }}$ of the Rome revision stated "the determination of the conditions under which these rights shall be exercised is reserved for the national legislation of the countries of the Union." ${ }^{67}$ This was an important revision for member countries like Great Britain, who did not recognize moral rights under their copyright law, and instead assured the other members that they offered protection of moral rights under common law or alternative legislation. ${ }^{68}$

Moral rights under the Berne Convention strengthened in the 20th century. In 1948, the Brussels Convention added a revision that contracting states ought to recognize moral rights after the death of the author. ${ }^{69}$ However, this revision was somewhat insignificant because the conference could not require contracting countries to do so as some countries, like Great Britain, did not protect moral rights under the country's copyright law. ${ }^{70}$ Therefore, each contracting country could decide to extend moral rights past the author's life. ${ }^{71}$ In 1971, the conference made it mandatory for contracting countries to recognize an

61. Id.

62. Id. at 28 .

63. Rushton, supra note 2, at 16.

64. Id.

65. $I d$.

66. Burger, supra note 21, at 28.

67. Berne Convention for the Protection of Literary and Artistic Works, art. $6^{\text {bis }}$, Sept. 9, 1886, 331 U.N.T.S. 217.

68. Burger, supra note 21, at 32.

69. Id.

70. $I d$.

71. Id. 
author's moral rights after death for at least the duration of the protection of the author's economic right. ${ }^{72}$ However, there was still an exception for countries that did not recognize moral rights in their domestic law. ${ }^{73}$

\section{Introduction of Moral Rights into the United States}

1. Why the United States did not initially participate in the Berne

\section{Convention}

Early on, the United States and the majority of Berne Convention member countries differed greatly in their approach to copyright. ${ }^{74}$ First, the United States had no participation in any major-multilateral-copyright convention until the 1950 s. ${ }^{75}$ U.S. copyright law fell below some of the minimal protections imposed by the Berne Convention. ${ }^{76}$ For example, the Berne Convention set a minimum duration of copyright protection of 50 years, but in the U.S., copyrights were only viable for 28 years. ${ }^{77}$ Moral rights were another significant difference between U.S. copyright law and the post-1928 Berne Convention. ${ }^{78}$ The inclusion of Article $6^{\text {bis }}$ became a major obstacle to American participation in the Berne Convention. ${ }^{79}$ In 1955, the United States joined the first major international copyright convention, the Universal Copyright Convention (UCC), which was more akin to U.S. law, ${ }^{80}$ focusing on economic rights while excluding moral rights. However, the UCC had limited international acceptance and was more of a temporary solution rather than a leading international copyright agreement. $^{81}$

72. $I d$. at 46 .

73. Id. at 33 .

74. Ralph Oman, The United States and the Berne Union: An Extended Courtship, 3 J.L. \& TECH. 71, 75 (1988).

75. Ginsburg \& Kernochan, supra note 14, at 2.

76. $I d$.

77. $I d$.

78. $I d$.

79. Lee, supra note 4 , at 805 .

80. Ginsburg \& Kernochan, supra note 14, at 2-3.

81. Mira T. Sundara Rajan, Moral Rights: Principles, Practice AND NEW TECHNOLOGY 139 (2011). 
2. How Moral Rights Differ from Traditional U.S. Copyright Law

United States' copyright law and moral rights differ in their guiding principles of copyright law regarding economic interests. While in France, the guiding copyright principle is to protect the pecuniary and personality rights of the artist, the United States' guiding copyright principle is that the artist or copyright owner is granted "economically exploitable rights to encourage the artist to create and to enrich society." 82 This is rooted in the Patent and Copyright Clause of the United States Constitution, which states that Congress has the power "to promote the progress of science and useful arts, by securing for limited times to authors and inventors the exclusive right to their respective writings and discoveries." 83 By emphasizing the importance of progress and usefulness, the clause arguably determines that the nation's guiding copyright principle is to enrich society. As a result, civil law countries have had to achieve economic objectives within the constraints of moral rights, whereas common law countries have not. ${ }^{84}$

Scholars have long expressed concerns that moral rights would threaten longstanding business and commercial arrangements. ${ }^{85}$ U.S. copyright law "is an economic privilege designed to serve the public interest, rather than an entitlement arising from the fact of creation." 86 It is clear that U.S. copyright law focuses on the economic interest and commercialism of works because the law places emphasis on the commercial exploitation of information. ${ }^{87}$ In a way, "American copyright law is an engine of the free market" where a monopoly is permitted only as it "promote[s] the progress of science and useful arts." 88 Some scholars explain this difference as due to the historical development of

82. Cheryl Swack, Safeguarding Artistic Creation and the Cultural Heritage: A Comparison of Droit Moral between France and the United States, 22 CoLUM.-VLA J.L. \& ARTS 361, 362 (1998).

83. U.S. CONST. art. I, $\S 8, \mathrm{cl} .8$.

84. Gerald Dworkin, The Moral Right of the Author: Moral Rights and the Common Law Countries, 19 COLUM.-VLA J.L. \& ARTS 229, 230 (1995).

85. Lee, supra note 4, at 812.

86. Swack, supra note 82, at 362 (quoting Neil Netanel, Alienability Restrictions and the Enhancement of Author Autonomy in United States and Continental Copyright Law, 12 CARDOZO ARTS \& ENT. L.J. 1, 9 (1994)).

87. Margaret Ann Wilkinson \& Natasha Gerolami, The Author as Agent of Information Policy: The Relationship Between Economic and Moral Rights in Copyright, 26 GOV'T INFO. Q. 321, 330 (2009).

88. RAJAN, supra note 81 , at 138 . 
European countries versus the United States. As a new nation, the United States dedicated most of its time to commerce and the pursuit of economic prosperity to thrive as a nation. ${ }^{89}$ On the other hand, upper - and middle-class Europeans could spend more time "enjoying, promoting, and purchasing art." ${ }^{90}$ This historical context provides support for diverging developments in copyright law, specifically concerning the United States and moral rights.

Part and parcel of the economic differences between moral rights and U.S. copyright law is the transfer of ownership. The framework of U.S. copyright law did not recognize an artist's ability to retain continuing rights in their work after a transfer of ownership. ${ }^{91}$ This is considerably in opposition with the inclusion of any moral rights, which attach to the artist and their work and are inalienable. While U.S. courts had an opportunity to address an artist's non-economic rights, caselaw reflects that the judiciary categorized such rights as uniquely foreign and relied on existing American law to provide equivalent rights. ${ }^{92}$ For example, in Vargas v. Esquire, Inc., an early case dealing with moral rights, the court noted that "what are called 'moral rights' of the author is the law of foreign countries." 93 In Vargas, the illustrator Alberto Vargas brought a suit under contract law against Esquire Magazine, who continued to publish Vargas' illustrations after canceling his contract. ${ }^{94}$ Originally, the illustrations were each published as a "Varga girl" but upon cancelation of the contract, Esquire published each illustration as an "Esquire girl." 95 In addition to the "Varga girl" title, all the pictures Vargas provided to Esquire were published with his name until Esquire began publishing the pictures at issue. ${ }^{96}$ Vargas argued that the publication of his work constituted false attribution of authorship because it no longer credited him as the creator. ${ }^{97}$ The court relied on the standard-form contract that Vargas had signed with Esquire, which granted Esquire the perpetual

89. Swack, supra note 82 , at 382 .

90. Id. at $381-82$.

91. Henry Hansmann \& Marina Santilli, Authors' and Artists' Moral Rights: A Comparative Legal and Economic Analysis, 26 J. LEGAL STUD. 95, 96 (1997).

92. Lee, supra note 4, at 806.

93. Id. (quoting Vargas v. Esquire, Inc., 164 F.2d 522, 526 (7th Cir. 1947)).

94. Swack, supra note 82, at 384.

95. Vargas, 164 F.2d at 524; Swack, supra note 82, at 384.

96. Vargas, 164 F.2d at 524.

97. Swack, supra note 82, at 384. 
and exclusive right to the images, so the court found the contract had divested Vargas "of all title, claim and interest in such drawings and designs." 98

In another case, Crimi v. Rutgers Presbyterian Church, artist Alfred Crimi signed a contract with a church to paint a 26 by 35 -foot mural inside the church. ${ }^{99}$ Eight years after completing his work, the church painted over the entire mural. ${ }^{100}$ Crimi brought a suit but the court, echoing the Vargas court, stated that based on the contract, Crimi had no cause of action because he contracted away all his rights by agreeing that once the mural was on the wall, it would become part of the church building and the copyright assigned to the owner (the church). ${ }^{101}$

Commentators have pointed out that artists can secure the right of integrity and attribution to their works under U.S. contract law. ${ }^{102}$ However, the above cases show that contract law is not exactly analogous to the moral rights protections from Article $6^{\text {bis }}$ of the Berne Convention because it is extraordinarily easy to contract away an artist's rights in their work, as seen in the Vargas and Crimi transfer of ownership contract provisions. This puts artists in a particularly difficult position due to a lack of bargaining power. Their goal is to get commissions and put their work out in the world, so they are often forced to agree to certain contract terms they would not otherwise agree to in order to secure a commission. ${ }^{103}$ They can either agree to a term like the one in Vargas or in Crimi, or they can lose out on a commission. Both the Vargas and Crimi courts mentioned that while the concept of moral rights was recognized in civil law countries, the United States had yet to accept the concept. ${ }^{104}$ Because the courts disposed of the

98. Vargas, 164 F.2d at 525-26 ("[T]he plaintiff by plain and unambiguous language completely divested himself of every vestige of title and ownership of the pictures, as well as the right to their possession, control, and use.").

99. 89 N.Y.S.2d 813 (N.Y. Sup. Ct., 1949); Swack, supra note 82, at 385.

100. Swack, supra note 82 , at 385 .

101. Crimi, 89 N.Y.S.2d at 814; Swack, supra note 82, at 385.

102. Lee, supra note 4 , at 807.

103. See generally The Biggest Challenges Artists Face During Their Career, ARTWORK ARCHIVE, https://www.artworkarchive.com/blog/the-biggest-challengesartists-face-during-their-career [https://perma.cc/K5DJ-E77B] (explaining that when the artist got a commission for the show Billions, she did not charge the amount that actually reflected her time because she likely would not have gotten the commission if she did).

104. Vargas v. Esquire, Inc., 164 F.2d 522, 526 (7th Cir. 1947); Crimi, 89 N.Y.S.2d at 818. 
moral rights claims, the artists would have a much stronger cause of action now that the United States has recognized some moral rights under VARA. Thus, contract law is not analogous to the protection offered by the Berne Convention.

\section{Factors that Led the United States to Adopt Moral Rights}

By the 1980s, the United States not having ratified the Berne Convention began to yield complications. ${ }^{105}$ U.S. industries that depended in part on copyright to generate revenue had to use an indirect "back door" method to achieve Berne-like protections, which was costly. ${ }^{106}$ This involved concurrently publishing copyrightable works in a Berne country to alter the work's country of origin. ${ }^{107}$ Additionally, non-membership raised some concerns with trading partners. ${ }^{108}$ If the United States "advocated a high level of copyright protection and enforcement" by trading partners, how come the country was "not a member of the most protective multilateral copyright treaty?"109 By the 1980s, adopting the Berne Convention was crucial for the United States to become a leader in international copyright. ${ }^{110}$ This was primarily due to the fact that Berne membership was a prerequisite before a country could adopt the much broader trade protections set out in the Agreement on Trade-Related Aspects of Intellectual Property ("TRIPs"), administered by the World Trade Organization ("WTO"). ${ }^{11}$ The United States negotiated TRIPs with the country's trading partners. ${ }^{12}$ Additionally, in 1984, the United States withdrew from the United Nations Educations, Scientific and Cultural Organization ("UNESCO"), which administered the UCC, so the country lost significant prestige within the treaty organization. ${ }^{113}$ And there was also urgency in protecting copyrighted intellectual property from pirating in Asia. ${ }^{14}$ All these forces eventually led President Reagan to sign legislation in 1989, which Congress had unanimously approved,

105. Ginsburg \& Kernochan, supra note 14, at 3.

106. $I d$.

107. Id.

108. Id.

109. Id. at 3-4.

110. RAJAN, supra note 81, at 139.

111. Id.

112. Id.

113. Swack, supra note 82, at 383 .

114. Id. 
bringing U.S. law into compliance with the Berne Convention. ${ }^{115}$ As a result, the United States claimed that U.S. law could provide minimal protections for artists' moral rights as required by the Convention and noted further that other member countries were not entirely in compliance; none of the other members objected. ${ }^{116}$

Through the VARA, Congress included moral rights within U.S. copyright law, ${ }^{117}$ doing so for the purpose of preserving artwork. Representative Edward Markey, a sponsor of the legislation, stated: "[a]rtists in this country play a very important role in capturing the essence of the culture and recording it for future generations." "118 The codification of VARA lays out the rights of certain authors to two moral rights: attribution and integrity. ${ }^{119}$ Under the right of attribution, an author of a work of visual art has the right to claim authorship of the work and prevent the use of their name as the author of any work of visual art which they did not create. ${ }^{120}$ The right of integrity provides that an author of a work of visual art can also prevent the use of their name as the author in the event of a distortion, mutilation, or other modification of that work that would be prejudicial to the author's reputation. ${ }^{121}$ Integrity also extends to protect against any intentional distortion, mutilation, or other modification of that work that would be prejudicial to the author's reputation and to prevent any destruction of a work of recognized stature. ${ }^{122}$

The application of these rights is limited in part by defining a "work of visual art" as a painting, drawing, print, or sculpture existing in a single copy in a limited edition of two hundred copies or fewer that are signed and numbered by the author. ${ }^{123}$ The definition also excludes specific works such as a work made for hire and audiovisual works. ${ }^{124}$ VARA's narrowness seems to attempt to alleviate some nervousness that major interest groups such as periodical publishers

115. Ginsburg \& Kernochan, supra note 14 , at 1.

116. Hansmann \& Santilli, supra note 91, at 97.

117. Ginsburg, supra note 1, at 478.

118. Susanna Frederick Fischer, Who's the Vandal? The Recent Controversy Over the Destruction of 5Pointz and How Much Protection Does Moral Rights Law Give to Authorized Aerosol Art?, 14 J. MArshall ReV. InTEll. Prop. L. 326, 339 (2015).

119. 17 U.S.C. $\S 106$ A.

120. $\S 106 \mathrm{~A}(\mathrm{a})(1)(\mathrm{A})-(\mathrm{B})$.

121. $\S 106 \mathrm{~A}(\mathrm{a})(2)$.

122. $§ 106 \mathrm{~A}(\mathrm{a})(3)$.

123. $§ 101$.

124. Id. 
and motion picture producers might have about exposure to moral rights claims when artists create contributions to their publications and films. ${ }^{125}$ Further, VARA limits coverage to objects of art rather than objects of mass production. ${ }^{126}$ VARA also allows an artist to waive the integrity and attribution rights via a written instrument signed by the artist that specifically identifies the work and the uses of that work. ${ }^{127}$ Proponents of moral rights in the U.S. find that the waiver provision is favorable for two reasons: it is in accordance with Article $6^{\text {bis }}$ of the Berne Convention because Article $6^{\text {bis }}$ does not directly prohibit waivers, and by requiring specificity, the waiver provision respects moral rights while allowing flexibility for other owners (copyright holders). ${ }^{128}$

The moral rights recognized in VARA are not completely equivalent to those in the Berne Article $6{ }^{\text {bis }} .{ }^{129}$ The three main differences include the duration of the moral rights, the distinction of intentional distortion, and the limited scope. ${ }^{130}$ As mentioned above, the Berne Convention recognizes moral rights past the artist's lifetime, but for works created in the U.S. under VARA, the rights expire upon the artist's death. ${ }^{131}$ Another interesting distinction is that the wording of VARA limits protection for intentional distortion or mutilation, whereas the Berne Article is not limited to intentional acts. ${ }^{132}$ Lastly, VARA only covers works of visual art, ${ }^{133}$ while the moral rights laws of other Berne member countries also encompass music, film, and other performing arts. Some argue that because of these differences, VARA is more of a halfway, patchwork approach that lacks legitimacy. ${ }^{134}$ But as Professor Justin Hughes mentions, "incremental improvement is better than none at all.",135

125. Ginsburg, supra note 1 , at $479-80$.

126. $I d$. at 480.

127. 17 U.S.C. $\S 106 \mathrm{~A}(\mathrm{e})(1)$.

128. Ginsburg, supra note 1, at 487-88.

129. Justin Hughes, American Moral Rights and Fixing the Dastar “Gap”, 3

UTAH L. REV. 659, 671 (2007).

130. Id. at $671-72$.

131. Id. at 672 .

132. Id.

133. Id.

134. Id. at 673 .

135. Id. 


\section{CURRENT ISSUES WITH VARA}

Although limited in scope, VARA has sparked intense criticism. Many believe that moral rights are incompatible with the American legal system. ${ }^{136}$ Concerns revolve around the idea that an artist's moral rights supersede the constitutionally based rights of those who have property interests in the works allowing them to make alterations. ${ }^{137}$ As discussed, VARA is the first legislated introduction of moral rights into American copyright law. While VARA is narrow in its application and seems to consider the rights of property owners, critics nonetheless believe that the law should not treat art uniquely by recognizing non-economic rights. ${ }^{138}$ Rather art should be treated based on common-law rules of property and contracts because these rules are fundamental to the United States' legal system. ${ }^{139}$ This tension has led to criticism of VARA based on constitutional and interpretation issues.

\section{A. First Amendment Constitutional Issues}

Commentators have raised the argument that VARA violates the First Amendment because it impedes an owner of artwork of recognized stature from destroying, mutilating, or modifying the artwork. ${ }^{140}$ Freedom of speech encompasses a broad range of expression, ${ }^{141}$ so any act of destruction, mutilation, or modification could fall under protected speech. The First Amendment protects both a creator's and other individuals' rights to communicate. ${ }^{142}$ In sum, creators are free to create, but the public is free to comment and criticize through words and expressive acts. ${ }^{143}$ This is where VARA and the First Amendment conflict because VARA prohibits the modification of an artwork, but such modification could be constitutionally protected expression.

136. Lee, supra note 4 , at 811 .

137. Id. at 814 .

138. Id.

139. Drew Thornley, The Visual Artists Rights Act's "Recognized Stature" Provision: A Case for Repeal, 67 CLEV. ST. L. REV. 351, 363 (2019).

140. See id. at n. 70.

141. Kathryn Kelly, Moral Rights and the First Amendment: Putting Honor Before Free Speech?, 11 U. MiAmi ENT. \& SPORTS L. REV. 211, 239 (1994).

142. Id. at $212-23$.

143. Id. at 213 . 
Copyright law generally implicates competing First Amendment rights. There are the rights of creators to speak freely, but there are also important speech interests of secondary users. ${ }^{144}$ Scholars since the 1970s have looked at the relationship between the First Amendment and the Copyright Act. ${ }^{145}$ How the First Amendment and VARA will coexist is an ongoing concern. Some scholars argue that the two simply cannot coexist. One has compared VARA's conflict with the First Amendment to the free-speech issues that arise from the prohibition of the mutilation or destruction of the American flag. ${ }^{146}$

On the other hand, caselaw suggests that courts have not been persuaded by defendants who assert their First Amendment rights in infringement actions. ${ }^{147}$ In Harper \& Row, Publishers, Inc. v. Nation Enterprises, the Supreme Court addressed the First Amendment defense to a copyright infringement claim. ${ }^{148}$ The Court found that First Amendment protection was already embodied in the Copyright Act's Fair Use defense. ${ }^{149}$ While the fair use defense technically applies to VARA because both are part of the Copyright Act, the House Report accurately notes that such a defense would likely be unsuccessful. ${ }^{150}$ The works protected under VARA are original works in single or limited editions of two hundred copies. ${ }^{151}$ Allowing destruction or alteration of these works through fair use would disregard VARA's core purpose. ${ }^{152}$ A pattern has emerged where courts routinely reject First Amendment defenses to copyright infringement claims. ${ }^{153}$ For example, the Fifth Circuit has recognized the tension between copyright law and the First Amendment but noted that "the First Amendment is not a license to trammel on legally recognized rights in intellectual

144. Claire Leonard, Copyright, Moral Rights and the First Amendment: The Problem of Integrity and Compulsory Speech, 35 COLUM. J.L. \& ARTS 293, 315 (2012).

145. Matt Williams, Balancing Free Speech Interests: The Traditional Contours of Copyright Protection and the Visual Artists' Rights Act, 13 UCLA ENT. L. REV. 105, 105 (2005).

146. Id. at 127 .

147. Kelly, supra note 141, at 236.

148. Id.

149. Id.

150. Id. at 243.

151. Id. at 244 .

152. Id.

153. Geri J. Yonover, The Precarious Balance: Moral Rights, Parody, and Fair Use, 14 CARdozo ARTS \& ENT. L.J. 79, 115 (1996). 
property." 154 While it seems a majority of scholars argue that VARA violates the First Amendment, there is some scholarship offering alternative arguments and solutions.

One scholar proposes a right of integrity based on due process that only requires notice to the first creator and a meaningful opportunity for the creator to object to the alteration of their work. ${ }^{155}$ In some ways, VARA already incorporates this due process in 17 U.S.C. $\S 113$ by setting out limitations on an artist's moral rights when the work of art is part of a building. ${ }^{156}$ The limitations apply when the owner of a building wants to remove a work of visual art that is a part of their building, and the removal would not destroy the work. ${ }^{157}$ In this situation, the artist's moral rights do not apply if the owner makes a diligent, good faith attempt, without success, to notify the artist of the intended action or the owner did provide notice in writing, and the artist failed, within 90 days, to remove the work. ${ }^{158}$ The drafting of VARA has demonstrated a strong congressional concern in balancing these conflicting interests.

\section{B. Interpretation Issues}

As courts apply VARA, two key interpretation issues have developed: the interpretation of the recognized stature standard and the aesthetic interpretation required by VARA.

\section{Recognized Stature \& Honor or Reputation: Different or Interrelated Concepts?}

One of the most discussed VARA interpretation issues is the definition of recognized stature because Congress did not include a definition or guidance on the interpretation of how to analyze whether a work has achieved recognized stature. The pertinent language as stated in VARA is as follows: "the author of a work of visual art . . . shall have the right to prevent any destruction of a work of recognized stature, and any intentional or grossly negligent destruction of that

154. Id. (quoting Dall. Cowboys Cheerleaders, Inc. v. Scoreboard Posters, Inc., 600 F.2d 1184, 1187-88 (5th Cir. 1979)).

155. Leonard, supra note 144 , at 318.

156. See 17 U.S.C. $\$ 113(d)(1)-(2)$.

157. Id.

158. $\S 113(d)(2)(A)-(B)$. 
work is a violation of that right." ${ }^{159}$ Additionally, VARA gives an artist "the right to prevent the use of his or her name as the author of the work ... in the event of a distortion ... of the work which would be prejudicial to his or her honor or reputation," and the artist has the right to prevent any destruction of their work which would be prejudicial to their honor or reputation. ${ }^{160}$ At first glance, it seems the recognized stature analysis should focus on the work itself, specifically whether the work has attained recognized stature, and the honor or reputation analysis should focus on the author. But these concepts are inevitably related. For example, if a new Jeff Koons work was discovered, would a court have to conclude that it did not fall under VARA protection because the work itself had not attained recognized stature on its own merits? Or would this new work automatically have recognized stature because the author is world-renowned? By the same token, can a less well-known artist seek to enforce their VARA rights under the claim that the destruction of their work harmed their honor or reputation, even if the work itself is remarkable? In developing the standard of recognized stature, courts have wrestled with the interplay of the artist and their work.

In Scott v. Dixon, the court makes clear that the recognized stature analysis must focus on the artwork in question and whether the artwork has acquired recognized stature. ${ }^{161}$ But immediately following this statement, the court recognizes that there might be situations where the artist's body of works as a whole has acquired recognized stature, so any work by that artist would fall under the scope of VARA. ${ }^{162}$ This analysis is echoed by the court in Cohen v. G\&M Realty L.P., where the court noted that caselaw reflects a variety of methods to determine recognized stature in concluding there is a legal basis for the plaintiffs' method of inferring recognized stature of the work based on the author's reputation. ${ }^{163}$

The interrelatedness of recognized stature and honor or reputation is further exemplified in VARA's legislative history. The House

159. $\S 106 \mathrm{~A}(\mathrm{a})(3)(\mathrm{B})$.

160. § 106A(a)(2), (3)(a).

161. Scott v. Dixon, 309 F. Supp. 2d 395, 400 (E.D.N.Y. 2004).

162. Id. ("For example, the court would be hard pressed to hold that a newly discovered Picasso is not within the scope of VARA simply because it has not been reviewed by the experts in the art community.").

163. Cohen v. G\&M Realty L.P., No. 13-CV-05612, 2017 WL 1208416, at*3 (E.D.N.Y. Mar. 31, 2017). 
Report for 106A Sections 3(A) and (B), which grants an artist the right to prevent the intentional destruction of a work that would be prejudicial to their honor or reputation and of a work of recognized stature, ${ }^{164}$ focuses on the honor or reputation standard required by the Berne Convention. ${ }^{165}$ Further, the report mentions the Committee's deletion of a per se standard for analyzing recognized stature. ${ }^{166}$ The Committee recognized the need for flexibility in interpreting the term honor or reputation. ${ }^{167}$ It is clear that the legislators intended for VARA to also protect less well-known or renowned artists. ${ }^{168}$ The legislative history provides the following guidance when applying the honor or reputation concept: "focus on the artistic or professional honor or reputation of the individual as embodied in the work that is protected." 169 While it is clear that recognized stature applies to the work and honor or reputation applies to the artist, the ways these concepts affect each other in the analysis is interesting. These nuances seem to be an integral part of VARA and of the moral rights doctrine due to the fundamental idea that an author's identity is intrinsically linked to and embodied by their work. It is a positive development to see courts willing to recognize different legal bases for plaintiffs to prove the recognized stature of their work because it ultimately serves to advance VARA's purpose "[to] protect[] both the reputations of certain visual artists and the works of art they create." 170

\section{Recognized Stature \& Community}

In analyzing whether a work attained recognized stature, courts have also turned to the opinions of the community. ${ }^{171}$ To further muddle the analysis of the recognized stature standard, the definition of community has been left to interpretation. ${ }^{172}$ Who makes up the

164. 17 U.S.C. $\S 106 A(a)(3)(A)-(B)$.

165. H.R. Rep. No. 101-514, at 7 (1990), as reprinted in 1990 U.S.C.C.A.N. 6915, 6917.

166. $I d$.

167. Id. at 15 .

168. Id.

169. Id.

170. Id. at 5 .

171. See Carter v. Helmsely-Spear, Inc., 861 F. Supp. 303, 325 (S.D.N.Y. 1994), rev'd on other grounds.

172. See generally id. at 325 (concluding that whether a work is of recognized stature depends on whether the work "is 'recognized' by art experts, other members of the artistic community, or by some cross-section of society"). 
relevant community? A default answer is an academic community where only the opinions of art critics, art professors and researchers, curators, and other art experts would matter in determining whether a work has attained recognized stature. But this idea has been met with criticism by commentators who believe that confining the community to only scholarly consensus is too narrow. ${ }^{173}$ Because there is no legislative guidance, courts are left to choose whether the plaintiff's or the defendant's interpretation is the most persuasive.

A New York District Court in Carter v. Helmsley-Spear found the recognized stature standard "is best viewed as a gate-keeping mechanism - protection is afforded only to those works of art that art experts, the art community, or society in general view as possessing stature." 174 Therefore, the court defined community to include art experts, art community, and society in general. This articulation of the requirement led to the Carter two-tiered test requiring a plaintiff to show: (1) that the visual art has "stature" (i.e., is meritorious), and (2) that this stature is recognized by art experts, other members of the artistic community, or by some cross-section of society. ${ }^{175}$ While the Second Circuit Court of Appeals reversed the district court's holding because the work in question qualified as a work made for hire, the two-tiered test was affirmed on appeal. ${ }^{176}$

The evidence presented in Carter resulted in a battle of expert witnesses. The plaintiffs in Carter were sculptors and artists. ${ }^{177}$ They had a continuing contract with the owners of a building in New York to design and install sculptures and other permanent installations in the building lobby. ${ }^{178}$ The managing agent of the property changed because the owner of the property changed. ${ }^{179}$ But the managing agent always extended the contract with the plaintiffs. ${ }^{180}$ Eventually, the owners of the property filed for bankruptcy and made statements to the plaintiffs that led them to believe the defendants intended to alter

173. U.S. COPYRIGHT OFF., supra note 6, at 79.

174. Carter, 861 F. Supp. at 325.

175. Keshawn M. Harry, A Shattered Visage: The Fluctuation Problem with the Recognized Stature Provision in the Visual Artists Rights Acts of 1990, 9 J. INTELL. PROP. L. 193, 198 (2001).

176. Id.

177. Carter, 861 F. Supp. at 312.

178. Id.

179. Id.

180. Id. 
or remove the artwork. ${ }^{181}$ Based on expert testimony, the court concluded that the work was of recognized stature. ${ }^{182}$ Plaintiffs called art professors and the president of the Municipal Art Society of New York as their expert witnesses. ${ }^{183}$ In contrast, defendants called an art critic who expressed disdain for contemporary art. ${ }^{184}$ The court weighed the testimony of all the expert witnesses and found the art critic's testimony was too colored by personal opinion and preferences, while the plaintiff's expert witnesses were more probative and thus persuasive. ${ }^{185}$ The way the Carter court defined community is extremely broad because it includes art experts, the art community, which is in and of itself not defined, and society as a whole. The parties' witnesses can thus be categorized into the art expert and art academia communities, which harkens back to the issue critics have with narrowly defining the term community to art experts.

Interestingly, VARA included guidance on recognized stature when it was first introduced in 1989. It provided that "in determining whether a work is of recognized stature, a court or other trier of fact may take into account the opinions of artists, art dealers, collectors of fine art, curators of art museums, conservators, and other persons involved with the creation, appreciation, history, or marketing of visual art." 186 This is the per se standard mentioned above in the recognized stature and honor or reputation section. This standard was eventually deleted by the Committee. According to the Committee, the inclusion of this standard would increase litigation by creating a battle of expert witnesses. ${ }^{187}$ Unfortunately, Carter shows that what the Committee feared is true even when VARA does not include the standard. Carter quickly became a battle of expert witnesses between professors for the plaintiffs and an art critic for the defendants. ${ }^{188}$ It seems natural that parties will resort to expert testimony to prove that a work is or is not of recognized stature because it is not otherwise clear how works can qualify for recognized stature. The Carter test begins the

181. Id. at 313 .

182. Id. at 324 .

183. Id. at 325 .

184. Id. at 326 .

185. Id.

186. H.R. 2690, 101st Cong. § 106A(a)(3) (1989).

187. H.R. Rep. No. 101-514, at 15 (1990), as reprinted in 1990 U.S.C.C.A.N. 6915,6925 .

188. Carter, 861 F. Supp. at 314, 326. 
discussion of how community should be defined in the recognized statue analysis.

\section{Aesthetic Interpretation}

VARA brings up an issue of aesthetic interpretation because it requires courts to base decisions on aesthetic considerations. ${ }^{189}$ The concerns about making an aesthetic judgment in law include courts being ill-equipped to engage in this analysis, the issue of the subjective and unpredictable nature of aesthetic judgments, and censorship. ${ }^{190}$ In the seminal case about aesthetic judgment in the courts, Bleistein $v$. Donaldson Lithographic Co., Justice Holmes stated that "it would be a dangerous undertaking for persons trained only to the law to constitute themselves final judges of the worth of pictorial illustrations, outside the narrowest and most obvious limits." 191 This case gave rise to the proposition that the artistry of a work should not serve as the foundation for copyright protection. ${ }^{192}$

Notwithstanding this proposition, aesthetic judgment is inextricably linked to copyright law. ${ }^{193}$ For example, courts exercise some artistic judgment when assigning joint ownership to a copyright or when determining the scope of copyright protection. ${ }^{194}$ Further, in some instances, a statute may require a judicial determination of artistic merit. ${ }^{195}$ For example, in Bleistein, the statute Rev. Stat. Section 4952 at issue referred to "works connected with the fine arts." 196 This is similar to VARA's works of recognized stature because both statutes call for judicial determination of aesthetic interpretation to conclude whether the work before the court connects with the fine arts or has recognized stature. ${ }^{197}$ VARA, like other copyright statutes,

189. See Christopher J. Robinson, The "Recognized Stature" Standard in the Visual Artists Rights Act, 68 FORDHAM L. REV. 1935, 1965 (2000).

190. Brian Soucek, Aesthetic Judgement in Law, 69 ALA. L. REV. 381, 446 (2017).

191. Robert Kirk Walker \& Ben Depoorter, Unavoidable Aesthetic Judgements in Copyright Law: A Community of Practice Standard, 109 Nw. L. REV. 343, 345 (2015).

192. Id.

193. Id. at 346.

194. Id.

195. Id. at 347.

196. Bleistein v. Donaldson Lithographing Co., 188 U.S. 239, 250 (1903).

197. See Walker \& Depoorter, supra note 191, at 347 ("Moreover, in some instances a judicial determination of artistic merit and ontology is explicitly mandated by the statute."). 
requires judges and juries to undertake aesthetic interpretation of works. ${ }^{198}$

VARA caselaw shows courts struggling to avoid aesthetic interpretation when determining if a work has recognized stature. ${ }^{199}$ In Carter, the court emphasized that the inquiry is based on the opinion of the artistic community and not on whether judges personally find the work of art aesthetically pleasing. ${ }^{200}$ The Second Circuit echoed this conclusion by noting that a district court's finding that a banner at issue in a VARA case was "visually appealing and demonstrated a great deal of artistic ability and creativity" was irrelevant because courts should avoid interpretations of VARA that require courts to assess the worth of a work of art. ${ }^{201}$ But passing aesthetic interpretation on to the artistic community and society necessarily results in a battle of expert witnesses during litigation, which ultimately puts the burden on the courts to determine who is more credible. ${ }^{202}$ In making this determination, courts make aesthetic judgments to some degree. ${ }^{203}$

To avoid undertaking aesthetic interpretation, some courts adhered to the guidance of VARA's two exclusions: promotional/advertising material and applied art. ${ }^{204}$ The Second Circuit determined that if it could identify any promotional purpose, the work would be disqualified from VARA protection no matter the quality of the art. ${ }^{205}$ This is similar to the applied art exclusion, where courts decide cases looking solely at a work's usefulness, thus avoiding questions of status. $^{206}$ There is clearly tension in the courts interpreting VARA to avoid aesthetic interpretation while resolving battles of expert witnesses to conclude whether a work is of recognized stature.

Critics of VARA denounce its explicit call for judicial aesthetic interpretation, and some commentators find the recognized stature determination is unique within copyright law. ${ }^{207}$ However, scholars analyzing copyright law noted that there are other areas requiring

198. Id.

199. Soucek, supra note 190, at 443.

200. Carter v. Helmsley-Spear, Inc., 861 F. Supp. 303, 325 (S.D.N.Y. 1994), rev'd on other grounds.

201. Pollara v. Seymour, 344 F.3d 265, 271 (2d Cir. 2003).

202. Soucek, supra note 190, at 444-45.

203. Id. at 445.

204. Id. at 443 .

205. Id.

206. Id.

207. Id. at 445 . 
courts to judge the parts of a work that are significant or the kinds of transformations that reach a certain threshold of value where they fall within the fair use defense. ${ }^{208}$ There is some degree of judicial aesthetic interpretation in many aspects of copyright law. As mentioned, even in Bleistein, where Justice Holmes wrote his cautionary statement, the statute called for some judicial artistic judgment. ${ }^{209}$ In that sense, VARA is not unique; however, Congress could alleviate the concern by giving courts guidance with a clear framework for determining whether a work is of recognized stature.

\section{ANALYSIS}

\section{A. The U.S. Copyright Office conducted a survey and created a report in 2019 analyzing moral rights.}

Although issues of interpretation persist, the introduction of moral rights into U.S. copyright law through VARA helps protect the country's cultural heritage and diverse artistic community. In essence, VARA serves two benefits to society: (1) enhancing the artistic, cultural heritage and (2) providing artists basic fairness by recognizing and protecting their rights of authorship and preventing the destruction of their works. ${ }^{210}$ While VARA has sparked intense criticism, it is a step toward figuring out how U.S. copyright law might protect noneconomic interests. It is doubtful the United States would ever implement moral rights protection to the extent outlined in Article $6^{\text {bis }}$ of the Berne Convention because economics serves as the guiding principle of U.S. copyright law. Additionally, any moral rights legislation will likely need to align with other aspects of U.S. law developed with economic advancement as their aim. However, the scope of VARA seeks to protect the rights of attribution and integrity of authors of works of visual art.

Congress rooted the goal of VARA in promoting the public interest by limiting the works of art covered by VARA to visual works whose protection and preservation serve an important public policy. ${ }^{211}$ VARA shows legislative recognition of the benefit of moral rights and

208. Id.

209. Bleistein v. Donaldson Lithographing Co., 188 U.S. 239, 249-52 (1903).

210. H.R. Rep. No. 101-514, at 15 (1990), as reprinted in 1990 U.S.C.C.A.N. 6915, 6916-17.

211. Id. at 6916. 
the attempt to carve out some moral rights protection while adhering to the economic foundations of U.S. law. For example, Congress carefully considered the exclusion of audiovisual works. ${ }^{212}$ While both artists of visual works of art and creators of films expressed concerns that their works were being altered or used without their consent, Congress considered the differences in the way these distinct creations are made and distributed. ${ }^{213}$ Films are generally collaborative efforts and works made for hire. ${ }^{214}$ Additionally, multitudes of copies are made of films, and the rights are licensed to various entities to display the film. ${ }^{215}$ Thus, if one copy of a film is destroyed or altered, it can be replaced, which is not the case with original works of visual art. ${ }^{216}$ Due to these key differences, Congress excluded audiovisual works from VARA protection because doing otherwise would highly interfere with the American copyright system. ${ }^{217}$

In 2019, the U.S. Copyright Office conducted a study and published a report examining moral rights. In reviewing the results of a moral rights symposium, the Copyright Office identified three principles to guide the analysis of U.S. moral rights: (1) the need to harmonize any proposals with precepts of U.S. law, like the First Amendment; (2) the need to acknowledge the critical importance of attribution and integrity rights to authors; and (3) the importance of recognizing that one size of moral rights protections cannot fit all industries. ${ }^{218}$ With these guiding principles in mind, the Copyright Office concluded that the existing patchwork of laws, supplemented by changes recommended in the report, would address a number of concerns raised by commentators as the Copyright Office was developing the report. ${ }^{219}$ The Copyright Office was not yet prepared to recommend the adoption of a new statutory moral right because of the significant changes to U.S. law that would represent. ${ }^{220}$ This stance supports the claim mentioned above that the U.S. is not likely to implement a more comprehensive moral rights statute similar to

212. Id. at 6921.

213. Id. at 6919.

214. Id.

215. Id.

216. $I d$.

217. $I d$.

218. U.S. COPYRIGHT OFF., supra note 6, at 27.

219. Id. at 36.

220. Id. at 35-36. 
Article $6^{\text {bis }}$ of the Berne Convention. But the recommendations suggested by the Copyright Office, if implemented, would further the goals of VARA by offering more guidance to courts when interpreting the recognized stature requirement.

The Copyright Office recommends that the standard of recognized stature should reflect that recognition of a work of art can originate from people in the geographic community where the art is located, or members of the general public who simply enjoy artregardless of their location or training. ${ }^{221}$ This extends the definition of community beyond the opinions from the "fine arts" academy and related scholarship. ${ }^{222}$ Specifically, the Office recommends adding the following language from the California Art Preservation Act:

In determining whether a work of visual art is of recognized stature, the trier of fact shall rely on the opinions of artists, art dealers, collectors of fine art, curators of art museum, and other persons involved with the creation or marketing of art, as well as the opinion of the relevant community. ${ }^{223}$

The addition of this language would help alleviate a few of the issues of VARA, which this Comment will address in turn. First, this language would give guidance to courts when determining whether a work is of recognized stature. This language expands and solidifies the second prong of the Carter two-tiered test defining community. Second, while a battle of experts seems unavoidable, this language would help ensure that artists who create public art or works that do not have an academic focus could still meet the standard. This language allows courts to consider whether a work is of recognized stature within the particular community where the art is located. This would also promote Congress' appreciation that less well-known artists should also be able to protect their honor or reputations. Third, by giving more guidance to the courts, the language would help reduce judicial interpretation of aesthetics. There will still be some degree of aesthetic interpretation because the courts would have to conclude who among the experts is more credible to determine which party would prevail. However, as mentioned above and in addition to Justice Holmes's statement, there are degrees of aesthetic interpretation throughout

221. Id. at 80 .

222. Id.

223. $I d$. at $80-81$. 
copyright law. The addition of this language would help limit the degree of subjectivity or unpredictability of aesthetic interpretation.

While federalizing the California Art Preservation Act language is certainly a step toward providing courts a clearer framework for the interpretation of VARA's recognized stature standard, the language still leaves open the definition of "relevant community." In some ways, this allows the flexibility for parties bringing or defending a VARA claim to propose who comprises the relevant community. This flexibility can be useful to further VARA's purpose because the community will change depending on the work in question. But leaving the language as is could lead to unintended issues of fairness regarding the application of the language.

The prevailing definition of community comes from the Carter two-tiered test that "stature is 'recognized' by art experts, other members of the artistic community, or by some cross-section of society." 224 However, the House Report for VARA states that courts interpreting the statute use the "generally accepted standards of the artistic community." 225 By not providing additional guidelines, there is the potential for tension in the courts if they interpret the definition of community differently; some courts might include the opinions of society more broadly, as suggested by the Carter test, and others might limit it to the artistic community. For example, one interpretation of the statute's current form is that the "relevant community" language extends only to the relevant community of art experts because of the immediate context rule of statutory interpretation. The people listed before the relevant community includes artists, art dealers, collectors of fine art, curators of art museums, and other persons involved in creating or marketing art. Using the immediate context rule, the relevant art community would be limited to the unifying aspect of all the preceding words, which is distinct types of art experts. This interpretation might be more in line with Congress' guidance of using the accepted standards of the artistic community. If Congress were to amend VARA to include the California language, Congress should consider expanding the definition of relevant community to leave a clear and strong framework for the judiciary.

224. Carter v. Helmsley-Spear, Inc., 861 F. Supp. 303, 325 (S.D.N.Y. 1994), rev'd on other grounds; Martin v. City of Indianapolis, 192 F.3d 608, 612 (7th Cir. 1999). 225. Cheffins v. Stewart, 825 F.3d 588, 600 (9th Cir. 2016) (citing H.R. Rep. No. 101-514, at 11,13). 
Any parameters added to the California language to further define the relevant community would have to balance the need for a clear framework with the need for flexibility in interpretation. As mentioned, the relevant community can vary depending on the type of art, ${ }^{226}$ but some constraints could be added as a consideration for courts when interpreting relevant community. For example, a relevant community could be defined geographically based on where the art is located. ${ }^{227}$ A sculpture in the center of a small town might not be recognized nationwide or internationally, but it might be of extreme importance to the citizens of that small town. In such case, the townspeople should be considered part of the relevant community.

Social media could also play a large role in shaping the relevant community of a work. ${ }^{228}$ If a work has a million likes and comments on Instagram, then Instagram might be considered part of the relevant community for that work and speak to its recognized stature. This will become an increasingly crucial factor as the art world continues to operate with a more significant online presence due to the COVID-19 pandemic. $^{229}$ Overall, the relevant community should be able to include regular, ordinary people who might not fit in the definition of the artistic community but who give a work recognized stature because they appreciate it, enjoy it, and have been touched by it. Further, certain factors like geography and the internet should be added to the language for consideration.

226. U.S. COPYRIGHT OFF., supra note 6, at 79. United States Copyright Office ("[T]he less established the artist and less relevant their work is to scholarly research, the more attention should be given to the community's opinion and not necessarily the expert's ...").

227. Id.

228. Blake Brittain, Protest Art Fate Tied to Obscure, Rarely Litigated Copyright Law, BLOOMBERG LAW (Jul. 16, 2020, 4:01 AM), https://news.bloomberglaw.com /ip-law/protest-art-fate-tied-to-obscure-rarely-litigated-copyright-law [https:/ /perma.cc/DN3N-X6M2]; Cohen v. G\&M Realty L.P., 320 F. Supp. 3d 421, 439 (E.D.N.Y. 2018) (finding the plaintiffs successfully showed their works achieved recognized stature through the use of their Folios showing evidence of their 5Pointz works in various media in additional to "social media buzz").

229. Blake Brittain, Protest Art Fate Tied to Obscure, Rarely Litigated Copyright Law, BLOOMBERG LAw (Jul. 16, 2020, 4:01 AM), https://news.bloomberglaw.com /ip-law/protest-art-fate-tied-to-obscure-rarely-litigated-copyright-law [https:/ /perma.cc/DN3N-X6M2]. 


\section{B. VARA at Work: The 5Pointz Litigation}

A recent case commonly known as 5 Pointz propelled the discussion above. ${ }^{230}$ The key question in the litigation was whether certain works of visual art had achieved recognized stature and, if they had, the value of the art. ${ }^{231}$ In 2002, the defendant enlisted the plaintiff, a distinguished aerosol artist, to turn a warehouse the defendant owned into an exhibition space for artists. ${ }^{232}$ The plaintiff and other artists rented studio spaces in the warehouse and filled the walls with aerosol art. ${ }^{233}$ Under the plaintiff's supervision, the site became known as 5Pointz and evolved into a major global center for aerosol art, attracting thousands of daily visitors, numerous celebrities, and widespread media coverage. ${ }^{234}$ In May 2013, the plaintiff learned the defendant sought municipal approval to demolish 5Pointz and turn it into luxury apartments. ${ }^{235}$ The plaintiff, along with numerous other 5Pointz artists, sued under VARA to prevent the destruction of the site. ${ }^{236}$ While pending litigation, the defendant began to paint over the artworks, destroy the building at night, and refused the artist's permission to recover any work that could be removed. ${ }^{237}$

The district court found that most of the works achieved recognized stature through the plaintiff's "plethora of exhibits and credible testimony, including the testimony of a highly regarded expert." 238 In making this determination, the district court noted that "courts should use common sense and generally accepted standards of the artistic community in determining whether a particular work is of recognized stature." 239 The district court found issue with the defendant's expert witness because she applied an overly restrictive interpretation

230. Judge Upholds $\$ 6.7$ Million Ruling for 5Pointz Graffiti Artists, CBS N.Y. (Feb. 21, 2020, 4:14 PM), https://newyork.cbslocal.com/2020/02/21/judge-upholds -6-7-million-ruling-for-5pointz-graffiti-artists/ [https://perma.cc/N27F-PNN6]; NY Court Approves \$6.7M Award for 5Pointz Graffiti Artists Whose Work Was Destroyed, NBC N.Y. (Feb. 20, 2020, 11:16 PM), https://www.nbcnewyork.com/news /local/ny-court-approves-6-7m-award-for-5pointz-graffiti-artists-whose-work-destroyed/2296684/ [https://perma.cc/W6TJ-4AFN].

231. Castillo v. G\&M Realty L.P., 950 F.3d 155, 163 (2nd Cir. 2020).

232. Id. at 162 .

233. Id.

234. Id.

235. Id.

236. Id. at 163 .

237. Id.

238. Id. at 167 .

239. Cohen v. G\&M Realty L.P., 320 F. Supp. 3d 421, 438 (E.D.N.Y. 2018). 
of the recognized stature standard that essentially only protected works deemed to be masterpieces. ${ }^{240}$ This harkens back to the battle of experts in Carter because the district court ultimately found the plaintiffs' experts more credible than the defendant's. ${ }^{241}$ The plaintiffs called artists, art appraisers, a conservator, the president of an auction house, and a curator as their expert witnesses. ${ }^{242}$ The defendant called an art lawyer and an appraiser as his expert witnesses. ${ }^{243}$ The district court was highly persuaded by the plaintiffs' art appraiser and found her testimony highly credible, whereas the district court found the defendant's art lawyer used an unduly restrictive interpretation of recognized stature. ${ }^{244}$ This is another example, in addition to Carter, that shows how a battle of experts is unavoidable.

On appeal, the defendant argued that the works were not of recognized stature for an array of reasons but, most importantly, because a majority of the works were temporary and the artists were aware of the potential that the building could be torn down. ${ }^{245}$ The court noted that there is nothing in VARA that excludes temporary artwork from attaining recognized stature and potentially falling within the scope of VARA. ${ }^{246}$ Further, the court agreed with the district court's explanation that VARA accounts for the possibility of art embedded in buildings being destroyed. ${ }^{247}$ Under $\S 113(\mathrm{~d})$, when art is incorporated into a site such that removing it would destroy the artwork, the property owner is required to obtain a written agreement signed by both the owner of the building and the artist specifying that installation of the work may subject the work to destruction, distortion, mutilation, or other modification, by reason of its removal. ${ }^{248}$ If in such a situation the art can be safely removed, then the property owner is required to provide written notice of the planned demolition and allow the artist 90 days to remove the work or to pay for its removal. ${ }^{249}$ Because the defendant in this case did not have a written instrument

240. Id.

241. Id. at 439.

242. Id. at 432.

243. Id.

244. $I d$. at 439.

245. Castillo v. G\&M Realty L.P., 950 F.3d 155, 167 (2nd Cir. 2020).

246. Id.

247. Id. at 168 .

248. Id. at 169 (citing 17 U.S.C. $\S 113(\mathrm{~d})(1)(\mathrm{B})$ ).

249. Id. 
and did not allow the artists to remove the artwork that could have been safely removed, the defendant's argument that the artists should have known of the possibility that their work could get destroyed is baseless. ${ }^{250}$ Ultimately, the Second Circuit affirmed the district court's ruling. ${ }^{251}$

The 5Pointz litigation demonstrates the importance of clarifying the recognized stature language and exemplifies the way VARA can balance property owners' rights with artists' moral rights. The evidence presented by both parties again demonstrates the typical battle of expert witnesses that will undoubtedly occur in these cases. Thus, while Congress removed guiding language because of a fear of creating a battle of experts, adding the guiding language recommended by the U.S. Copyright Office will not aggravate the inevitable. It should, however, provide some framework when courts are presented with all of the evidence. Because of the current lack of guidance, it is not difficult to imagine that another court could find the 5Pointz defendant's expert witness more persuasive because that court could feel a narrower interpretation of VARA is necessary. The guiding language from the California Art Preservation Act with the addition of the factors described above makes the opinion of the relevant community tantamount to the opinions of art historians, collectors, curators, and dealers. This should give courts a greater footing when it comes to rendering a judgment. It also has the potential of addressing the concern that VARA currently excludes certain types of art that it should cover. ${ }^{252}$ By not focusing solely on academic merit, the 5Pointz court was able to consider the stature of particular graffiti works within the relevant and appropriate community for that type of art. ${ }^{253}$ Combining the guiding language proposed by the U.S. Copyright Office with additional guiding language to define relevant community will give courts a clearer, more objective framework for making recognized stature determinations.

Another important development from the 5Pointz litigation is how succinctly the Second Circuit described the way VARA balances property owners' rights with artists' moral rights. It would be unwise to discuss the benefits of VARA without touching on the exceptions

250. Id. at $168-69$.

251. Id. at 173 .

252. U.S. COPYRIGHT OFF., supra note 6, at 79.

253. Id. 
carved out in $\S 113(\mathrm{~d})(1)(\mathrm{B})$. Critics can be quick to conclude that any moral rights protection interferes and impedes other important rights such as property rights. However, VARA seeks to balance property owners' rights by including specific provisions when an artwork is incorporated within or made part of a building. As explained above, $\S$ $113(d)(1)(B)$ permits the destruction of a work when it is part of a building so long as the property owner, upon commission of the work, creates a written instrument that the artist also signs explaining that the work might be subject to destruction upon removal. ${ }^{254}$ The provision goes a step further and when a work can be safely removed, the property owner is to inform and give the artist 90 days to either remove the work or pay for its removal. ${ }^{255}$ In other words, $\S 113(\mathrm{~d})(1)(\mathrm{B})$ limits the rights discussed above allowing an author to prevent the destruction of a work that would harm their honor or reputation or allowing an author to prevent the destruction of a work of recognized stature if the work in question is incorporated into or made part of a building. 256

Proponents of property rights who do not see the value in moral rights might find these additional requirements encroach upon property rights. But it is important to recognize the benefits property owners can acquire when they commission or otherwise allow artwork to be incorporated within or applied to their buildings. For example, in 5Pointz, the defendant saw his building become a hub for the world's largest collection of aerosol art. ${ }^{257}$ The defendant had nothing to do with the daily operations of the site because the plaintiff did the curating, sought artists, and kept the site clean and safe. ${ }^{258}$ The site became a major pop culture attraction drawing thousands of daily visitors and served as the backdrop for Now You See Me, a 2013 movie, and a concert tour stop by the musician Usher. ${ }^{259}$ This benefit would extend to the defendant even after the destruction of the artworks because the defendant stood to benefit economically from the popularity of the site when he marketed the new luxury residences. ${ }^{260}$ To allow a property owner, like the defendant in 5Pointz, to benefit in this way

254. 17 U.S.C. § $113(\mathrm{~d})(1)(\mathrm{B}))$.

255. $\S 113(d)(2)$.

256. § $106 \mathrm{~A}(\mathrm{a})(3)(\mathrm{A})-(\mathrm{B})$.

257. Cohen v. G\&M Realty L.P., 320 F. Supp. 3d 421, 433 (E.D.N.Y. 2018).

258. Id.

259. Id.

260. Id. at 441 . 
because of the artist without giving the artist any recourse is fundamentally unfair. It assumes that the property owner's rights are more significant or important than the artist who made the work that elevated the property site to one of recognized stature. By addressing the relationship between property owner and artist, VARA seeks to protect the interests of the artist and recognizes that they have rights that must be acknowledged and balanced with the property owner's rights. Although $\S 113(\mathrm{~d})(1)(\mathrm{B})$ does not change the core of the discussion regarding interpretation issues and the recognized stature standard, it is still an important aspect of VARA that must be noted when arguing that VARA and moral rights have a place within U.S. copyright law.

The Supreme Court declined to hear a challenge brought by the defendant of the 5Pointz case. ${ }^{261}$ As a result, a $\$ 6.75$ million award to the plaintiffs will stand. ${ }^{262}$ Additionally, the denial allows the Supreme Court to remain silent on the issue of VARA's implication on the First Amendment and on the vagueness of the recognized stature provision. Although the Court will not speak on the First Amendment issue in the context of 5Pointz, scholars have proposed different doctrines the Court could employ to analyze VARA's interaction with the First Amendment. The first of these doctrines is strict scrutiny. The government will have to overcome the burden of strict scrutiny by articulating a compelling interest and showing that the regulation is narrowly construed to achieve that interest. ${ }^{263}$ Additionally, there must not be any less restrictive means of achieving the governmental goal. ${ }^{264}$ If VARA was put under a strict scrutiny review, it would likely succeed. The government's interest in passing VARA was to encourage the preservation of cultural heritage, give artists the ability to adequately protect their attribution and integrity interests, and bring the United States into conformity with the Berne Convention. VARA is already quite narrow as it only applies to works of visual art, ${ }^{265}$ of

261. Kyle Jahner, High Court Lets Artists' \$6.75M 5Pointz Graffiti Win Stand, BLOOMBERG LAW (OCT. 5, 2020, 8:57 AM), https://news.bloomberglaw.com/ip-law /high-court-lets-artists-6-75m-5pointz-graffiti-win-stand [https://perma.cc/TP7C9P5K].

262. Id.

263. Kelly, supra note 141, at 238.

264. Id. at 239.

265. 17 U.S.C. $\S 106 A(a)$. 
limited quantity, ${ }^{266}$ and of recognized stature. ${ }^{267}$ Lastly, it allows artists to waive their rights by contract ${ }^{268}$ and balances property interests by allowing property owners to destroy works if they make a diligent effort to notify artists that their work will be removed or destroyed. ${ }^{269}$ Any further narrowing would prevent the fulfillment of the statute's objectives. The Supreme Court's denial of the 5Pointz petition creates an interesting situation for the future of VARA and moral rights in the United States. The Court's denial could suggest that it did not find a persuasive argument in the petitioner's assertion that VARA violates the First Amendment. It also denies an opportunity for the Court to encourage Congress to make amendments to the Act to provide more guidance. As a result, VARA remains as it was prior to the 5Pointz litigation.

\section{CONCLUSION}

The enactment of VARA has led to an array of criticism rooted in the belief that the doctrine of moral rights cannot coexist with principal tenets of U.S. law. One of these concerns is the tension between VARA and the First Amendment. Copyright, by default, places some limitations on the freedom of expression and speech. The Supreme Court addressed a First Amendment defense in a copyright case, concluding that the fair use defense already took into consideration First Amendment rights. The tension between VARA and the First Amendment is and will almost certainly be present, but that tension exists to some extent with much of copyright law. Thus, it should not be used as a single point of criticism to call for a complete repeal of the Act. Another concern exemplified in the 5Pointz litigation is the issue of property rights versus natural rights. This is definitely a fundamental issue that Congress considered in the writing of VARA, as seen with the exceptions in $\S 113(\mathrm{~d})(1)(\mathrm{A})$ for works incorporated into or made a part of buildings. Again, this tension of competing rights should not be used as the sole cause to repeal the Act.

VARA serves an extremely important purpose. Through enacting it, Congress recognized artists have interests in securing attribution

266. $\S 101$ (defining a work of visual art as a work in a limited edition of 200 copies or fewer signed and consecutively numbered by the author).

267. § $106 \mathrm{~A}(\mathrm{a})(3)(\mathrm{B})$.

268. $\S 106 \mathrm{~A}(\mathrm{e})$.

269. $§ 113(d)$. 
for the integrity of their work, and these protections enhance cultural heritage and promote artistic creation. Additionally, VARA helps promote a public interest goal that is larger than the individual economic interests of owners and artists. A comprehensive moral rights doctrine akin to those in France and Germany is likely beyond the scope of anything that Congress can implement in accordance with U.S. legal precepts. However, VARA bridges the gap between American and continental European copyright law by introducing some moral rights into U.S. copyright law.

Caselaw, in the 31 years since VARA's enactment, shows the need for some modifications to give the judiciary a clearer and more defined framework when interpreting the recognized stature standard of VARA. Implementing the California Art Preservation Act language, as recommended by the U.S. Copyright Office, would help alleviate interpretation issues, but it would still require further amendments because the language refers to the relevant community. If left as is, it could continue to cause the same interpretation issues that courts face today when determining who makes up the relevant community even though the addition of "relevant" begins to create a clearer framework. The additional guiding language could fall along the lines of explaining that the relevant community includes a variety of people interested in or touched by works of art. Implementing the California Art Preservation Act language and further adding guiding language to define the relevant community would create a more defined framework and make it clearer to courts, artists, and interested third parties what works fall under VARA protections. Amending VARA in this way would help ease some tensions on the courts, which in turn would ensure VARA is utilized as it was intended: to provide artists basic fairness and preserving artworks. 